\title{
COLLECTIVE BARGAINING
}

\author{
THE REPORT ${ }^{1}$
}

\author{
BY J. D. B. HarRISON
}

\begin{abstract}
OOLLECTIVE BARGAINING means the negotiation of binding agreements concerning wages and working conditions by representatives of an employer and representatives of his employees. In some cases, col. lective bargaining agreements are negotiated on behalf of all the employers in an industry, on the one hand, and all employees of that industry on the other. In addition to clauses covering working conditions and wages, collec. tive bargaining agreements may contain some provision for the airing of grievances and the settlement of disputes. They are usually effective for a specified period of time (one or more years) after which negotiations for a new agreement are to be undertaken.
\end{abstract}

The practice of collective bargaining has been highly developed by the trade unions and the principles involved are endorsed by organized labour throughout the English speaking world. The election of bargaining repre. sentatives is usually based on two principles, namely, (1) By majority vote the employees of a given unit of industry may elect bargaining representa. tives or may decide to ask a trade union to appoint representatives on their behalf. Any agreement reached is binding on all employees, whether they support the union of the majority or not. (2) An employee organization appointing a collective bargaining representative must not have in its ranks any employer representation nor may it accept financial support from employers.

Until recently the idea of collective bargaining received little or no serious consideration from engineers and scientists in Canada. Terms of employment offered by employers were accepted or not accepted according to the individual judgment of the prospective professional employee. In a few cases associations of professional men approved scales of remuneration as being fair and just for certain classes of service but there was no machinery for supporting these proposals. In 1943, however, legislation requiring em. ployers to enter into collective bargaining with their employees was adopted in the province of Ontario, and it was found in practice that some professional men became subject to collective bargaining agreements negotiated by trade unions. In effect, they found themselves subject to agreements formulated without participation by anyone representing professional interests.

IA report by the President to the Annual Meeting, January 30, 1945, on developments in "Collective Bargaining" Legislation as they affect members of the Society. 
On 17th February, 1944, the Dominion Government adopted Order in Council P.C. 1003, known as the Wartime Labour Relations Regulations. These regulations, adopted under authority of the War Measures Act, provided for compulsory collective bargaining in all industries or undertakings ordinarily within the legislative authority of Parliament or essential to the efficient prosecution of the war. The regulations provided that any province desiring to do so could, by legislative action, make these regulations applicable to all industries within the province. This step was taken by Ontario and several other provinces.

It is provided that "a person employed in a confidential capacity or having authority to employ or discharge employees" should not be considered an employee for the purposes of the regulations. Dominion civil servants are also excluded. The regulations adopt the principle of collective bargaining on behalf of all employees of an industry or industrial unit by representatives ap. proved by majority vote with the exception that, where a group of employees belong to a craft which is recognized as distinguishable from the employees as a whole "in accordance with established trade union practice", the trade union representing that craft may appoint representatives to negotiate a separate agreement on their behalf.

The regulations authorize the appointment of a Board, known as the Wartime Labour Relations Board (National), consisting of a chairman, vicechairman, four representatives of organized labour and four representatives of employers. The chairman of the Board is Mr. Justice G. B. O'Connor. It is the duty of the Board to deal with matters concerning the interpretation and enforcement of the regulations including, among other things, the certification of collective bargaining representatives.

Before the adoption of P.C. 1003 the Government consulted both employers and labour, but did not consult professional workers as such. Nevertheless, when the regulations were made public it seemed more than likely that many professional workers would automatically become subject to them. Thus the question of collective bargaining as it might affect engineers and scientific workers suddenly, and without warning, became a matter urgently requiring consideration by all those affected.

It was thought that the vast majority of engineers and scientists would not wish to be subject to the provisions of P.C. 1003, and the representatives of a number of professional societies asked the Wartime Labour Relations Board (National) for an opportunity to present their views on this matter. An appointment was made for 12th April, 1944, and representatives of fourteen professional and scientific societies, including the Canadian Society of Forest Engineers, met in Ottawa on 11th April to discuss the terms of approach to the Board. As a first step, the group elected Mr. A. E. MacRae, patent solicitor and member of a number of professional societies, as chairman and Dr. L. Austin Wright, general secretary of the Engineering Institute of Canada, was appointed secretary. This proved to be the first meeting of what has subsequently come to be known as the Committee of Fourteen. 
In the course of the discussions it became apparent that different views as to the proper course of action were held by representatives of different groups: Furthermore, it was recognized that the representatives of the various societies had not had time to ascertain the vietws of their members on this very im. portant question. It was, therefore, decided to ask the Board to exempt professional people from inclusion in collective bargaining agreements for a period of six months in order to give those present an opportunity to study the situation and to learn the wishes of their many thousands of individual members. This the Board consented to do. At a further meeting of the committee each representative undertook to refer the questions at issue to the organization he represented and to report back to the future meeting to be held in mid-summer.

The next meeting took place on 15 th August. Summaries of the results of questionnaires which had been sent to members of the associations concerned were presented and it was evident that the wishes of the overwhelm. ing majority might be summarized as follows:

1. Engineers and scientists wish to have the right to enter into collective bargaining negotiations with their employers. Furthermore, they believe that collective bargaining on their behalf should be conducted solely by professional men

2. They did not wish to be made subject to the terms of P.C. 1003 in its present form, nor to be bargained for by trade unions.

3. They desired the adoption of a new Order in Council specifically designed to meet the needs of engineers and scientists with respect to collective bargaining.

The committee decided, in view of the opinions summarized above, to proceed with the preparation of a new draft Order in Council. A sub-committee was appointed for this purpose and authorized to obtain the services of the best legal talent available and whatever other advice they thought necessary. The sub-committee later retained Mr. V. C. MacDonald, who had recently resigned from the post of Associate Deputy Minister of the Department of Labour, to prepare the required draft.

On 3rd October the Committee of Fourteen met again in Ottawa to consider the draft of the proposed Order in Council, the salient points of which are touched upon in a brief appended to this report. After a lengthy dis: cussion and the suggestion of a number of amendments, the draft order was approved in principle and a small committee consisting of Messrs. A. E. MacRae, W. P. Dobson, and R. E. Heartz, was appointed to present it for the consideration of the Hon. Humphrey Mitchell, Minister of Labour. This was done on 8th November. The Minister indicated that he proposed to take advice on this subject, including that of the Wartime Labour Relations Board (National). 
At the October meeting a resolution was adopted to the effect that all expenses connected with the proceedings, except travelling expenses of delegates, should be pooled and contributed by the participating associations pro rata according to membership.

On 29th November, a circular letter was sent out by Mr. M. M. Mac. lean, Chief Executive Officer of the Board, to more than fifty representatives of societies and individuals who were considered to have a special interest in the matter of collective bargaining for professional workers, inviting them to attend a meeting of the Board to be held in the Railway Committee Room of the House of Commons at Ottawa, at 10 a.m., on 9th January, 1945. He requested that any briefs to be submitted should be in his hands not later than 31st December, 1944, and that organizations holding similar views should arrange for joint representation in so far as that was practicable. This invitation made necessary a further meeting of the Committee of Fourteen in Ottawa, on 20th December, when a draft brief intended for presentation to the Board was read by the chairman and unanimously approved. It was arranged that the small committee who had presented the draft order to the Minister should also appear before the Board, and the chairman requested that he be provided with a formal letter from each association or society which supported the draft order, authorizing his committee to speak on its behalf.

At the public hearing Mr. MacRae tabled copy of the draft Order in Council prepared for the Committee of Fourteen, together with letters auth. orizing him to speak on behalf of fifteen national and provincial societies. $\mathrm{He}$ then read his brief, making it clear that the engineers and scientists concerned believed that it should be considered by the Government itself. The Board was requested to forward the brief to the Minister of Labour and to recommend adoption of the proposed Order in Council.

The proposals of the Committee of Fourteen were opposed by the Canadian Manufacturers Association and by several representatives of organized labour. Opposition to the draft Order-in-Council was also voiced by speakers representing the Association of Technical Employees, who claimed to have a number of professional men among their members, and the Canadian Association of Scientific Workers, a new organization claiming some 225 professional members in Montreal, Ottawa, and Winnipeg.

The Canadian Manufacturers Association expressed the opinion that professional engineers and scientists should be entirely excluded from collective bargaining agreements. Others opposing the committee's proposals claimed that every employed person had an inherent right to bargain collectively and supported the view that professional people should be subject to the provisions of P.C. 1003. It appeared from the comments of some of those opposing the adoption of a new Order in Council that there would be little 
if any opposition to amendment of P.C. 1003 in such a way as to ensure groups of professional engineers and scientists the right to select representatives of their own choice to carry on collective bargaining negotiations on their behalf. Such a solution, however, might leave the question of professional representation on the Board itself unanswered.

At the conclusion of the meeting Mr. MacRae very ably replied to the more important criticisms which had been made of the position taken by the Committee of Fourteen. He laid emphasis on the special responsibilities of the professional worker and the peculiar position he occupies between management and labour. The Board then reserved its decision and adjourned.

Further action to be taken by the Committee will depend on the attitude adopted by the Minister of Labour after he has considered the opinions of the Wartime Labour Relations Board (National). In the meantime, it can be stated that the Committee of Fourteen has every intention of continuing to press for a solution of the collective bargaining problem which shall be satisfactory to the engineers and scientists of Canada.

\section{THE BRIEF'}

\section{To The Wartime Labour Relations Board (National)}

1. On April 12 last a committee representing some fourteen organizations of professional engineers and scientists appeared before you and requested that such workers be excluded from the operation of P.C. 1003 at least until they had been given an opportunity of considering the effect of this law on their position in national life. They had not been consulted in the drafting of the law. You were good enough to order that such workers be excluded from the operation of the order for a period of at least six months. Pursuant to your letter of November 29, 1944, we present herein the collated views of the professional scientific workers of Canada.

2. Following our meeting with you the Committee requested each of the organizations to inform its own members of the problems and considerations involved in this new law and to request them to indicate their individual wishes in the matter. There are some 40,000 workers in this group. The several organizations did a very good job in the matter of informing their members as to the considerations involved. The results were collected by means of individual ballots by some of the organizations and by branch meetings held across the country by other of the organizations. In gross the results indicated substantial unanimity on the part of such workers in favour of compulsory collective bargaining for professional scientific workers but by an agency of their own choosing and constituted by professional people. As illustrative of the vote, the following figures may be quoted-

1. Presented to the Wartime Labour Relations Board (National) on January 9, 1945, bs representatives of organizations of profesional workers. 
$92 \%$ were in favour of collective bargaining under a new Order-inCouncil relating specifically to this group of persons. Only $1 \%$ indicated a preference for trade unions as their bargaining agents.

3. The new order was drafted and the undersigned Committee was instructed to present it to the Government. A copy of the order which we presented to the Honourable Humphrey Mitchell, Minister of Labour, on November 8 is attached hereto.

4. The essential features of this order, which distinguishes it from P.C. 1003 are -

(a) "Employee" is defined as a person employed in his capacity as a professional worker and excludes persons employed in any other capacity distinct from their professional or scientific training.

(b) "Professional Worker" is defined so as to describe the types of em. ployees to be covered. It includes three groups as follows:

(i) Members of the provincial registering bodies, and those in training for registration.

(ii) Members of national technical societies formed for the purpose of promoting the advancement of knowledge in the various scientific professions.

(iii) Those who hold degrees in several stated branches of science, or who are taking courses leading to such degrees, in or from universities or colleges recognized by the Board.

(c) It seeks to include professional employees of the Dominion Government.

(d) References to "trade unions" have been replaced by the term "employees' organizations" as descriptive of the collective bargaining group.

(e) It is proposed that a National Board (smaller than the present Board, and more directly representative of professional workers and their employers) and Provincial Boards constituted on the same principle, be set up to administer the proposed order. It is assumed that the Dominion and the Provinces will make similar arrangements as under P.C. 1003 as to the body (and its personnel) to administer the Order in each province and as to the classes of matters within the general jurisdiction of the National Board which are to be administered by the provincial body.

5. The following reasons are advanced in support of the proposed Order:

(a) By virtue of their professional and scientific training, such employees are as distinctly distinguishable from the general body of employees as are employees belonging to a craft-union: they also possess a community of interests not shared by the generality of employees. 
(b) By the nature of their work they are differentiated from the generality of employees. The duty of professional workers as defined in the proposed Order possesses the following characteristics:

(i) It is predominantly intellectual and varied in character, as op. posed to routine mental, manual, mechanical or physical work.

(ii) It requires the consistent exercise of discretion and judgment of its performance.

(iii) It is of such character that the output produced cannot be standardized in relation to a given period of time.

(iv) It requires knowledge of an advanced type in a feld of science or learning customarily acquired by a prolonged course of specialized intellectual instruction and study, as distinguished from a general academic education and from an apprenticeship, and from train. ing in the performance of routine mental, manual, or physical processes.

(v) It is predominantly original and creative in character, as opposed to work which can be performed by a person endowed with general manual or intellectual ability and training.

(c) It is hard to fit these employees into an Order designed for employees generally and built largely around the conventional trade unions. The Board which is to regulate collective bargaining by such employees should be directly representative of such workers and of employers of such workers. The present Board is representative of employers and workers as a whole.

(d) Professional scientific workers usually occupy a functional position which is between labour and management. Their function has primarily to do with advising on, the reporting on, the designing of, the supervising of the construction of various projects and research, as well as the operation of various processes and the like. In performing these functions they are restricted to the use of established formulae, rules and procedures by which the facts surrounding the project in hand are measured quantitatively. They have no opinion on the project until the facts are so established. This constitutes the basic principle of the training they receive as students usually at con. siderable cost to the country. In the national interest nothing should be permitted to hamper efficient utilization in research and industry of that skill.

To place professional scientific workers performing such functions in a group with management or labour for bargaining purposes, would tend to reduce the efficiency with which they can perform their major function, because of the new loyalty which they would have to assume in relation to the group to which they are associated. 
It is quite natural for the individual to develop loyalty to an association of which he forms a part. It is apparent that, if such workers found that they could not exhibit loyalty to the group and at the same time efficiently perform their professional function, their social pasition in the group would be unhealthy. The effect on creative or productive capacity of the group would be bad, to the detriment of all. If a few professional scientific workers join in an association with a large number of other workers who are not hampered by the necessity for factually analyzing the project in hand, it seems clear that they will be forced to follow the will of the majority, even if that should be contrary to the scientific facts to which they are committed.

We suggest that this is an important factual consideration which should not be valued lightly in the improvement of employment relations.

(e) We believe that professional scientific workers acting as independent units in industry in the matter of collective bargaining will be able to do much to promote improved relationships between labour and management.

(f) We are sure best results can be achieved by operating under a separate order since the effort will be free from the prejudices which have developed, not unnaturally, in the procedures followed by trade unions and management.

(g) We realize that difficulties will arise by the provision of the separate procedure, but we believe they will be fewer and the benefits greater to both labour and management.

(h) Professional workers are now organized in Associations and Societies throughout Canada for the purpose of disseminating technical and scientific information, establishing standards of practice, controlling the practice of the professions and disciplining their members. They have prepared and they enforce codes of ethics applicable to professional workers. All of these activities have for their object the rendering of competent and adequate technical services which are absolutely essential to the welfare, safety and health of the public. These services are distinct from those rendered by the generality of employees, and distinguish professional workers as having a community of interests which will be jeopardized if they are included in the operations of an order with other employees.

If the professions are to serve the public as they should and as they desire to do, they may with propriety ask the Government to recognize them as a distinct element in the community as Labour is now recognized, to accord them equivalent status and privileges, and to do nothing which will jeopardize the unity of the professions. Indeed we believe our group would be negligent in its duty to the betterment of human relationships if we did not strongly urge this point of view.

(i) The Dominion Government has already recognized the validity of the principle involved by enacting a code of wartime manpower controls for professional engineers and scientists different from that applying to employees in general, and by placing the administration of these controls under the Wartime 
Bureau of Technical Personnel, a body set up at the request of our national scientific organizations, under the direction of the Honourable Humphrey Mitchell, Minister of Labour. The benefits accruing therefrom have been acclaimed widely by all who know the facts.

That is to say, the Government has acknowledged by a special law that professional workers, because of their training and experience, form a distinct class different from the generality of employees. By placing the operation of the Bureau in the hands of professional persons, through the medium of its administrative officers and Advisory Board, the Government has acknowledged the competency of professional workers to deal with problems in the field of their special work.

The postwar period will present problems as formidable as those now facing us. They include many more than collective bargaining. Their solution will require the concentrated and combined efforts of all those competent and willing to attack them. Professional workers' contribution to their solution will be based upon the capacity which their training and experience has given them. To be effective, it must not be impeded by diversifying their efforts and submerging them in groups not familiar with their methods.

(j) The practice of professionl engineering is controlled by law in each of the Provinces. Under such laws a professional engineer may be denied the right to practice his profession. In this respect, too, the position of such professional workers differs from that of members of a trade union.

(k) The proposed Order is an adaption of P.C. 1003 to the specific case of professional and scientific workers. No change of the basic principle or machinery is involved.

6. The hope for improvement in such relations in fields of employment lies in the greater exercise by individuals of the sense of responsibility to others in accomplishing a desired object. Responsibility for the discharge of loyalty to a group must not be placed, by law, in opposition to responsibility for recognizing and pursuing the course dictated by the facts involved in the project in hand. Professional scientific workers have an ingrained sense of responsibility to their job:-to define the best way the project can be carried out successfully.

7. It is of interest here to quote a statement made at a recent meeting of the American Chemical Society by Mr. Bernard M. Baruch, one of the outstanding leaders in the United States in organizing production in both this and the last war:

"A trained scientific researcher thinks only of the subject he has before him; not of any ideology, not of himself, not of his publicity, not of what anybody thinks of him or his associates, not of another job--but only one thing-what do the facts justify. How helpful it would be if we could have more trained minds to see errors, to pass judgment and guide action before it is too late. 
It is hoped that in the future, even in the fields of economic, political and social matters, national and international, more of these trained scientific minds, those experienced searchers after facts, truths and realities, will be asked to help solve them."

8. No reflection on trade unions is implied or intended; the proposal merely reflects the fact that trade unions being differently constituted need not be invoked as agencies of collective bargaining by professional workers who are organized on the different principle of professional training.

No great loss can accrue to trade union membership, as such unions have seldom brought professional workers into union ranks as such; on the contrary it is in accordance with the spirit of P.C. 1003 that the professional worker should be free, if so minded, to select non-union agencies or to avoid agencies altogether and choose individual representatives directly.

It is of as much interest to labour as a class as it is to management as a class to have an independent body to advise on the practical possibilities of a given proposal.

9. We understand the Honourable Minister of Labour is awaiting your views before dealing with our request. In the interest of the purpose for which P.C. 1003 was enacted we strongly urge that you recommend it.

Respectfully submitted on behalf of Professional Engineers and Scientists by their officially appointed Committee.
R. E. HEARTZ
W. P. DOBSON
A. E. MACRAE.

THE DECISION ${ }^{1}$

WARTME LABOUR RELATIONS BOARD (NATIONAL):

Professional Employees

Hon. Humphrey Mitchell, Minister of Labour, today announced that the Wartime Labour Relations Board (National) has submitted a recommendation that the Wartime Labour Relations Regulations be applied for a further six months at least, to employees described as professional or scientific personnel.

In recommending that the Regulations be continued as applying to professional workers for the present, the Board proposes to subdivide bargaining units so that employees engaged in a professional capacity may elect or appoint (as the case may be) bargaining representatives on their own behalf in a proper case. It is felt by the Board that this course will give professional employees an opportunity to acquire some experience in collective bargaining. if they so desire, and when they have this experience they will be in a position to decide as to what kind of collective bargaining they want.

1. A press release on February 13,1945 , by the Information Division, Department of Labour, Ottawa. 
The Board promises to review further the application of the Regulations to professional workers after the lapse of this six month period.

(The Wartime Labour Relations Regulations cover professional and scientific employees in the same manner as other employees, safeguarding the right to organize, and giving organizations consisting of this type of employee the right to apply for the naming of bargaining representatives to negotiate with employers in regard to their working conditions. Professional or scientific employees who have authority to engage or discharge other employees, are not covered by the Regulations, however).

On January 9, 1945, the National Board had heard representations from a number of organizations representing professional workers, in which the Board was asked to recommend the enactment of a new Order-in-Council, applicable exclusively to professional employees. Professional organizations making representations to the Board at the time included the American Institute of Electrical Engineers, the Chemical Institute of Canada, the Canadian Society of Forest Engineers, the Royal Architectural Institute of Canada, the Association of Professional Engineers of Manitoba, the Ontario Architects' Association, the Institute of Radio Engineers, and other organizations.

Any change in the present Regulations was opposed by representatives of the Canadian Manufacturers' Association, the Trades and Labour Congress of Canada, the Canadian Congress of Labour, the Canadian Association of Technical Employees, and the Canadian Association of Scientific Workers.

During the hearings a representative of the Canadian Universities objected to collective bargaining for University professors.

In the report, now filed with the Minister of Labour, the Board points out that the cost of a new National Board and the necessary Provincial Boards to deal with professional employees separately, would be substantial, and the proposal to include professional employees who influence the hiring or dis. charging of scientific personnel would not work out satisfactorily.

The present report of the National Board to the Minister is unanimous. 


\section{ERIC GRAHAM MCDOUGALL}

Eric Graham McDougall, M.A., B.Sc.F., died on December 29 in London, Ontario, where he had been in hospital for about a week. He was a son of the late Judge Joseph E. McDougall and a grandson of the late Hon. William McDougall, one of the Fathers of Confederation.

He came to the University of Toronto from Ridley College. After taking his M.A. degree he entered the Faculty of Forestry and graduated in 1911. $\mathrm{He}$ was with the Dominion Forest Service for a short time and then joined the B. C. Forest Branch from which he enlisted for service with the McGill Section of the Princess Patricia's Light Infantry. While serving in France he suffered the loss of his foot. After the war he joined the Dominion Meteorological Service in Toronto and later became librarian of the Department of Zoology in the Royal Ontario Museum.

He always kept up his interest in forestry and, although not a member of the Society, frequently attended the meeting of the Southern Ontario Section.

He is survived by his widow, Mrs. Dorothy Aylmer McDougall, his brother and three sisters.

\section{NEWS AND NOTES \\ VACANCY FOR FORESTER}

The post of Deputy Director, Imperial Forestry Bureau, will fall vacant about July or August, 1945. The bureau is one of the group of centres of information organized under the Executive Council of the Imperial Agricultural Bureaux. It is located at and works closely with the Imperial Forestry Institute, Oxford. The Director of that Institute has general supervisory charge of the bureau, but the Deputy Director is the chief executive officer of the bureau and as such is directly responsible to the Executive Council.

2. The work of the Bureau is to collect, collate and make available to forestry officers and to research workers in sciences applied to forestry, information on forestry and the sciences allied thereto. The main divisions are: Forest policy, Silviculture, Management, Protection, Utilization, Allied Sciences.

3. Applications are invited for the post of Deputy Director.

Salary. $£ 600-25-£ 800$. If the officer appointed is not already a member of the Federated Superannuation System for Universities, he is required, after one year's probation, to become a Member.

Initial salary is dependent on qualifications and experience.

Note: It is very probable that the salary scale may be improved in the near future. 
Qualifications:

A degree or other similar qualification in forestry.

Actual forestry experience or work in a forestry reséarch institute-the wider the experience the better.

Some knowledge of German; additional linguistic knowledge or any experience of bureau or similar work are advantageous.

Physically fit and energetic.

4. Applicants should state qualifications in detail, mentioning any contributions they have made to forest literature or research. At least two references should be given, preferably from those under whom they have worked on forestry.

5. Applications should be addressed to:

The Secretary,

Executive Council of the Imperial Agricultural Bureaux,

2 Queen Anne's Gate Buildings, London, S.W. 1.

6. Further information can be obtained from the Secretary of the Executive Council or from the Director of the Imperial Forestry Institute, Oxford.

\section{FORESTRY MEMORIAL SCHOLARSHIP}

President $\mathrm{H}$. J. Cody announces that The Forestry Memorial Scholarship of $\$ 250.00$ has been awarded this session to John Walter Giles, Faculty of Forestry, University of Toronto, on the basis of his standing in the Ontario Grade XIII examinations. Mr. Giles entered first year Forestry in September, 1944, from Humberside Collegiate Institute. He came to Toronto from Peterborough some years ago.

\section{J. W. B. SISAM JOINS TORONTO FORESTRY FACULTY STAFF}

Dr. Cody, President of the University of Toronto, announces the appointment of J. W. B. Sisam, B.Sc., M.F., to the position of Associate Pro fessor of Forestry in the University of Toronto, from July 1, 1945.

Mr. Sisam was born in Springhill, N.S. and was educated in Aberdeen High School, Moncton, and Provincial Normal School, Frederiction, N.B. He graduated from the University of New Brunswick, Faculty of Applied Science, Department of Forestry, in 1931, and was awarded his Master of Forestry degree from Yale University in' 1937. He worked with the Domin. ion Forest Service until 1939, in Nova Scotia, New Brunswick, Quebec and Ontario, mainly on specialized biological forestry research. In 1935 he was appointed Deputy Director of the Imperial Forestry Bureau at Oxford University. Professor and Mrs. Sisam and their young sons Peter and John David are expected to arrive from England during the summer. 